\title{
Experimental research of the influence of differential settlement on the upper frame structures
}

\author{
Chunyan REN ${ }^{1, a}$, Bin YAN ${ }^{1, b}$ \\ ${ }^{1}$ College of Civil Engineering and Architecture, University of Jinan, Jinan 250022, China \\ aemail:wgq_rchy@163.com, bemail: cea_yanb@ujn.edu.cn
}

Keywords: foundation; differential settlement; frame structure; experimental study

\begin{abstract}
Architectural accidents caused by differential settlement of foundation occured regularly in countries. In order to better understand the influence law on upper frame structure caused by differential settlement of foundation and reduce the occurrence and damage of accident in frame structure, this paper systemically summarize the influence law of internal force and deformation on upper frame structure caused by differential settlement of foundation, which provided important reference value for the design and reinforcement of frame structure.
\end{abstract}

\section{Introduction}

With the progress of times, owing to the fact that multivariate architectures are used on a large scale and the hydrogeological condition is complex and various, the foundations should have very high security and reliability. Differential settlement of foundation cause not only that the building can not be use normally, but also that the upper structure occur the redistribution of internal force which can change subgrade reaction. It is one of the major reasons causing damage to the upper structure [1,2]. The research about the impact on upper frame structures caused by differential settlement of foundation has become a hot topic at home and abroad. Jie MA studied the space work for the frame structure with unequal settlement by SAP2000 and ANSYS, and accurately analyzed the similarities and differences of laws for the structure development [3]. Qiang JIA and Xin ZHANG analyzed the deformation and displacement of the beams caused by the differential settlement of foundation by finite element software ANSYS, and had obtained the influence law of cracks on upper frame structure caused by differential settlement of foundation [4]. Overall, the literature mostly used engineering examples or the finite element analysis to research the influence law on upper frame structure caused by differential settlement of foundation [5,6,7,8], lacking of experimental verification. In this paper, it uses two test models of single-layer multi-span frames to explore the influence law of stresses and cracks on upper frame structure caused by differential settlement of foundation be achieved through pressing down on the top of settling column.

\section{Design of Test}

The research object was the four layer office building(the grade of concrete is C30), which was reinforced concrete frame structure with $6 \times 3$ span. The longitudinal spans were all $4.5 \mathrm{~m}$, the transverse spans were respectively divided into $6 \mathrm{~m}, 3 \mathrm{~m}, 6 \mathrm{~m}$, the height of the first floor was $3.6 \mathrm{~m}$, and the height of the others were $3 \mathrm{~m}$. According to the similarity theory, this test established the 3:1 model which selected a longitudinal bay for the first floor of the office building. the floor plan of model structure is shown in Fig. 1. Based on the similitude theory, the size and reinforcement of the specimen were scaled. The cross-sectional dimensions of the frame columns were $150 \mathrm{~mm} \times 150 \mathrm{~mm}$, and the cross-sectional dimensions of the frame beams were $100 \mathrm{~mm} \times 150 \mathrm{~mm}$ in the test component. The frame beam and frame column reinforcement are shown in Fig. 2. In order to ensure the transport and the specimens during the test has stabilization, setting the ring beam in the bottom member. Ring beam, beams and columns were connected to form a space frame structure, but settling column and ring beam were not connected. The loads of test structure were composed of frame, floor, wall and live loads, and they converted into equivalent sand according to the similarity principle to be added to 
the corresponding frame beam. Two frame specimens were produced respectively. One is working condition S1 used to make settlement test of side column KZ-5. The other is working condition S1 used to make settlement test of middle column KZ-6. In the process of test, the horizontal displacement of settling column was constraint and only the vertical displacement can occur [9]. Jacks on the top of corresponding settling column exerted anti pressure on the specimen, in order to produce the vertical displacement of settling column and achieve the effect of differential settlement of foundation. the test equipment are shown in Fig. 3.

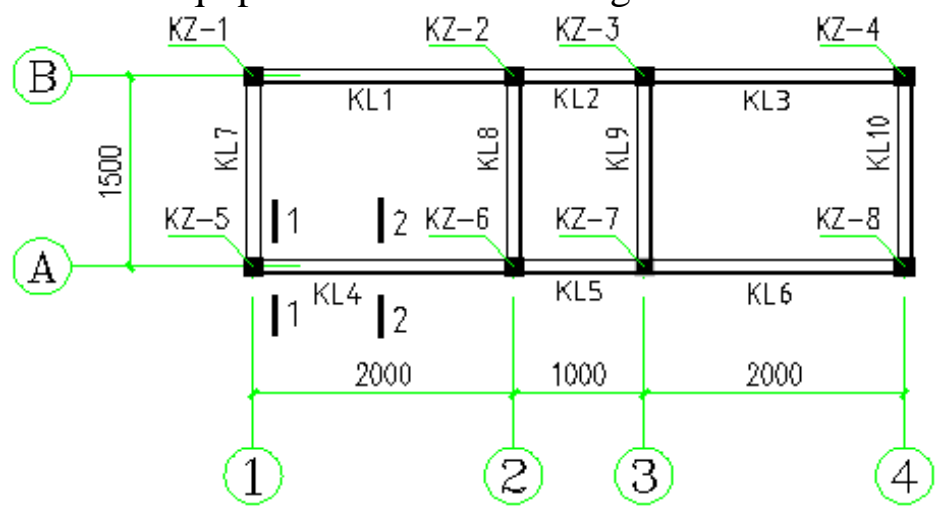

Fig. 1. The floor plan of model structure

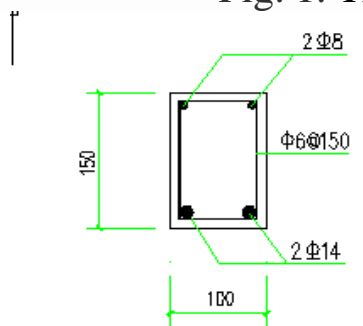

(a) Section 1-1

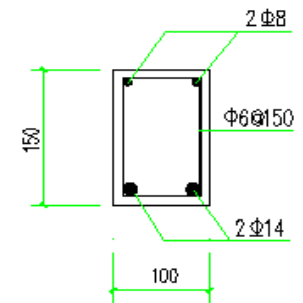

(b) Section 2-2

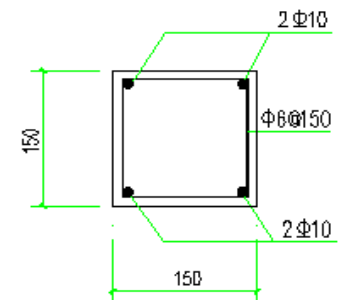

(c) Section of frame column

Fig. 2. The frame beam and frame column reinforcement

\section{Phenomenon and Analysis of Test}

\section{Development of Cracks}

In condition S1, with the development of settlement, the failure discipline of each beam was as follows in turn: When $\Delta_{5} / \mathrm{L} 7<0.0053$ (the ratio of vertical displacements of KZ-5 and the span of beam $\mathrm{KLi}$ ), and $\Delta_{5} / \mathrm{L} 4<0.004$ (before the settlement was $8 \mathrm{~mm}$ ), the frame structure had no cracks. When $\Delta_{5} / \mathrm{L} 7=0.0053$, and $\Delta_{5} / \mathrm{L} 4=0.004$ (settlement was $8 \mathrm{~mm}$ ), on the top surface of beam KL7 away from the end of settling column appeared the first lateral micro-crack whose width was 0.04 $\mathrm{mm}$, and with the development of settlement, on the top surface of beam KL4 away from the end of settling column also appeared the micro-cracks. When $\Delta_{5} / \mathrm{L} 7=0.008$, and $\Delta_{5} / \mathrm{L} 4=0.006$ (settlement was $12 \mathrm{~mm}$ ), on the top surface of beam KL7 away from the end of settling column appeared the second crack. When $\Delta_{5} / \mathrm{L} 7=0.0107$, and $\Delta_{5} / \mathrm{L} 4=0.008$ (settlement was $16 \mathrm{~mm}$ ), beams KL7 and KL4 all appeared several tiny cracks at the bottom and sides near the end of settling column. When $\Delta_{5} /$ L7 $=0.0187$, and $\Delta_{5} / \mathrm{L} 4=0.014$ (settlement was $28 \mathrm{~mm}$ ), cracks of beam KL7 away from the end of settling column were developed to $2 / 3$ of beam height along the depth, and at the same time the surface concrete at bottom loosed and peeled off. When $\Delta_{5} / \mathrm{L} 7=0.0347$, and $\Delta_{5} / \mathrm{L} 4=0.026$ (settlement was $52 \mathrm{~mm}$ ), at the bottom of column KZ-6 and beam KL5 all appeared lateral micro-cracks. When $\Delta_{5} / \mathrm{L} 7=0.0373, \Delta_{5} / \mathrm{L} 4=0.028$ (settlement was $56 \mathrm{~mm}$ ), width of cracks of beam KL4 on the top surface away from the end of settling column had developed to $5 \mathrm{~mm}$. When $\Delta_{5} /$ $\mathrm{L} 7=0.0633$, and $\Delta_{5} / \mathrm{L} 4=0.0475$ (settlement was $95 \mathrm{~mm}$ ), beam KL7 and KL4 all appeared a through crack whose width was $5 \mathrm{~mm}$, and the structure was damaged.

In condition S2, with the development of settlement, the failure discipline of each beam was as follows in turn: First on the top surface of beam KL5 away from the end of settling column appeared 
micro-cracks. Then on the top surface of beam KL4 and beam 8 away from the end of settling column appeared the first lateral micro-cracks. At the bottom of beam KL5 away from the end of settling column appeared tiny cracks, and at the bottom of column KZ-7-beam KL5 node appeared micro-cracks. The first crack of KL8 away from the end of settling column keep on developing, and at the same time appeared the second micro-crack. Settlement was continuing, and the top crack of beam KL5 away from the end of settling column was developed to $1 / 5$ of beam height along the horizontal quickly. Meanwhile, beam KL5 appeared several tiny cracks at the central bottom and near the end of settling column, and at the bottom of KL4 near the end of settling column also appeared a tiny crack. With the development of settlement, the top crack of beam KL5 away from the end of settling column was developed rapidly along the horizontal and the width of crack was greater than 5 $\mathrm{mm}$. In the meantime, the surface concrete at bottom loosed and peeled off. Settlement was continuing, at the bottom of KL5 near the end of settling column appeared cracks, and the top concrete loosed slightly. At the central bottom of KL8 appeared cracks, and the width of crack of KL8 away from the end of settling column had developed to greater than $5 \mathrm{~mm}$. Settlement was continuing, at the bottom of beam KL4 40cm distant from KZ-6 column appeared a through crack that width was $1 \mathrm{~mm}-3 \mathrm{~mm}$. Settlement was continuing, the bottom concrete of beam KL5 away from the end of settling column was crushed. The crack of beam KL5 away from the end of settling column was developed to 2/3 of beam height, and top crack of beam KL8 away from the end of settling column was developed to 2/3 of beam height along depth. The bottom concrete of beam KL5 away from the end of settling column peeled off severely, and the bottom of beam KL5 near the end of settling column was separated from column about $4 \mathrm{~mm}$. Column KZ-6 was separated from the bottom of all joins connected to beam, and the structure was destroyed. Cracks of settling column-beam joints are shown as Fig. 4.
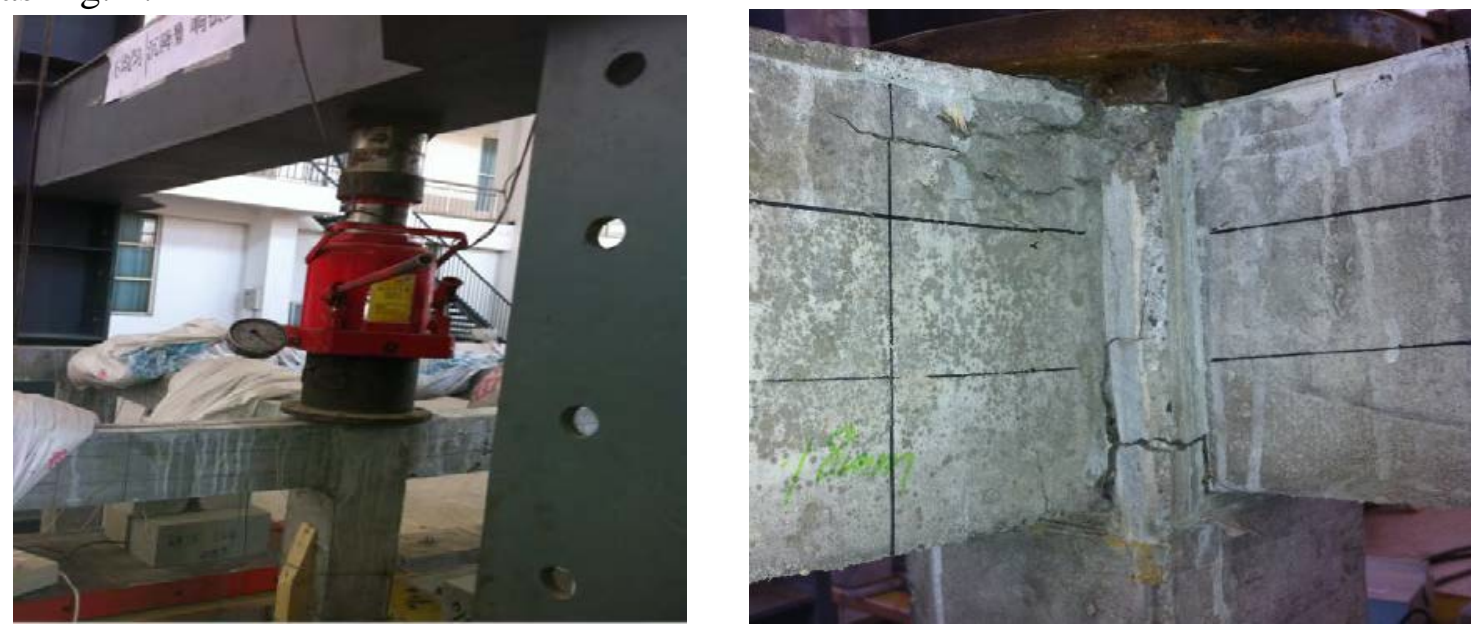

Fig. 3. Test equipment

Fig. 4. In condition S2, cracks of settling column-beam joints

\section{Stress variation in the frame structure}

According to the strains recorded on the corresponding key part of beam-column at all stages, stress value was calculated based on stress-strain relationship.[10]. Stress and settlement curve were given, in which tension stress was positive number and the compressive stress was negative. In condition S1, the stress influence on frame structure caused by uneven settlement is shown in Fig. 5.

In condition S1, the corresponding relationship curve of settlement of settling column $\mathrm{D}$ and the stress value of adjacent column $\sigma$ are shown in fig. 5 (a). As can be seen from the fig. 5 (a): In the experimental process,load-bearing column next to settling column bore compressive stress on the side which near the settling column, when it sustained tension stress on the side away from the settling column; Under the same stress conditions, the influence of column KZ-1 was the largest.

In condition S1, the corresponding relationship curve of settlement of settling column $\mathrm{D}$ and the mid-span stress value of the adjacent beam $\sigma$ was shown in fig. 5 (b). As can be seen from the fig. 5 (b): With the increase of sedimentation value, mid-span stress at the top of beam KL7 was converted from tension stress to compressive stress; At the same time, mid-span stress at the bottom of beam 
KL7 was converted from compressive stress to tension stress; Mid-span stress at the top of beam KL4 was always compressive stress, while at the bottom of beam KL4 was always tension stress. It is indicated that column affected by uneven subsidence, and mid-span stress of beams and the length of the beam had close relationship.

In condition S1, the corresponding relationship curve of settlement of settling column $\mathrm{D}$ and the stress value at both ends of the adjacent beam $\sigma$ is shown in fig. 5 (c). As can be seen from the fig. 5 (c): With the increase of sedimentation value, stress of beam KL4 on the top of the end closing settling column and at the bottom of the end away from settling column was always compressive stress. When $\Delta_{5} / \mathrm{L} 4=0.012$, stress of beam KL4 at the bottom of the end closing settling column converted to tension stress from compressive stress, and stress of beam KL4 on the top of the end away from settling column converted to compressive stress from tension stress.

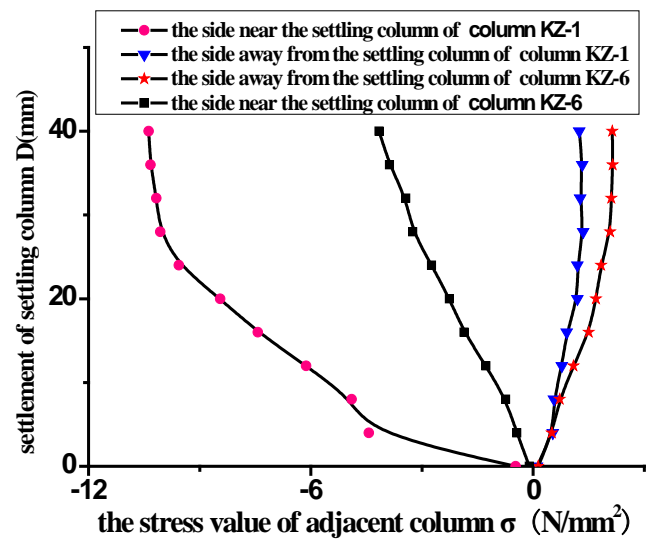

(a)

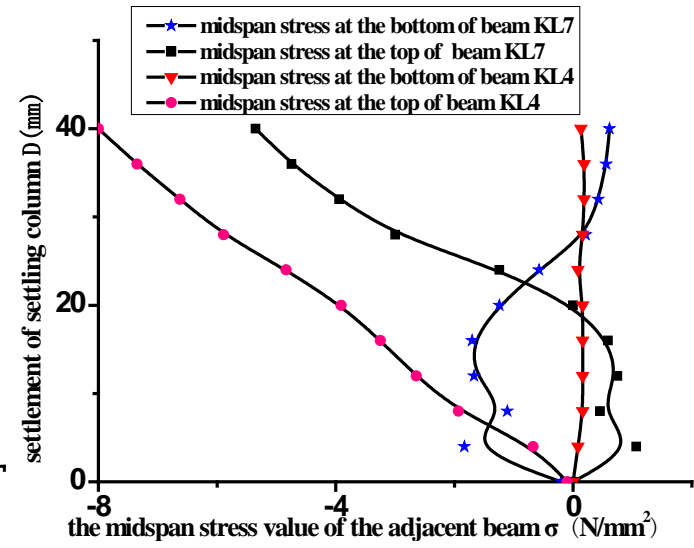

(b)

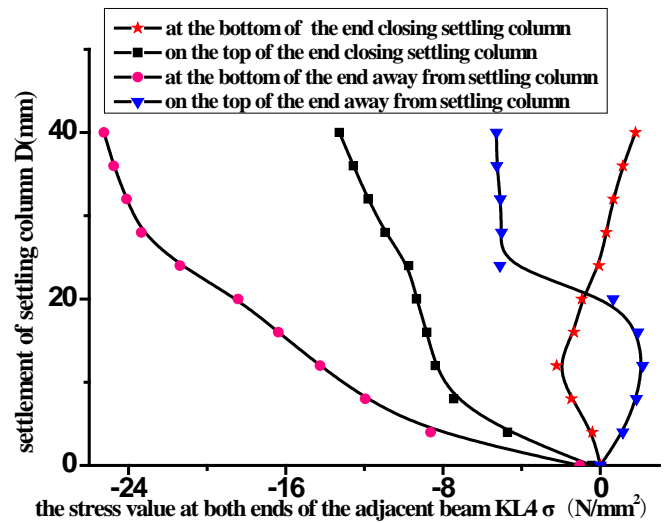

(c)

Fig. 5. In condition S1, a: the corresponding relationship curve of settlement of settling column $\mathrm{D}$ and the stress value of adjacent column $\sigma$. b: the corresponding relationship curve of settlement of settling column $\mathrm{D}$ and the mid-span stress value of the adjacent beam $\sigma$. c: the corresponding relationship curve of settlement of settling column D and the stress value at both ends of the adjacent beam KL4 $\sigma$.

In condition S2, the stress influence on frame structure caused by uneven settlement is shown in

Fig. 6. Tension stress was positive number and the compressive stress was negative. 


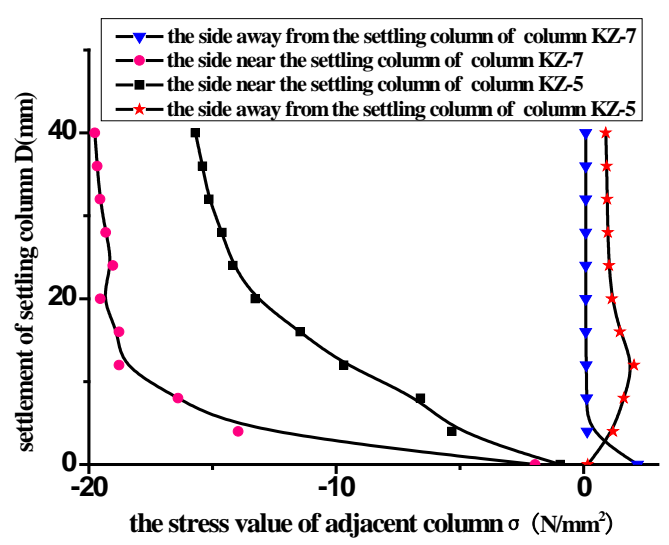

(a)

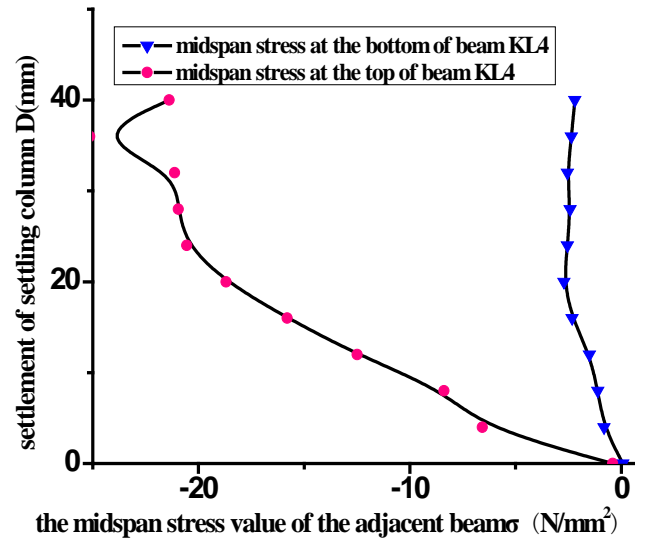

(b)

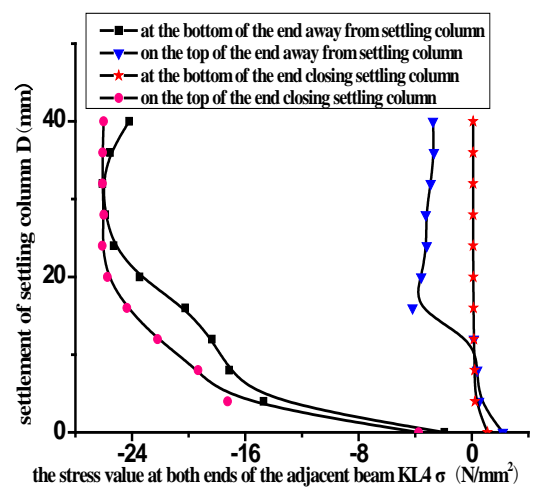

(c)

Fig. 6. In condition S2, a: the corresponding relationship curve of settlement of settling column D and the stress value of adjacent column $\sigma$. b: the corresponding relationship curve of settlement of settling column $\mathrm{D}$ and the mid-span stress value of the adjacent beam $\sigma$. c: the corresponding relationship curve of settlement of settling column D and the stress value at both ends of the adjacent beam KL4 $\sigma$.

In condition S2, the corresponding relationship curve of settlement of settling column D and the stress value of adjacent column $\sigma$ was shown in fig. 6 (a). As can be seen from the fig. 6 (a): In the experimental process, load-bearing column next to settling column bore compressive stress on the side which near the settling column, when it sustain tension stress on the side away from the settling column; Due to the constraints of adjacent frame beams, the stress on the side away from the settling column of KZ-7 was significantly smaller than that of KZ-5.

In condition S2, the corresponding relationship curve of settlement of settling column D and the mid-span stress value of the adjacent beam $\sigma$ was shown in fig. 6 (b). As can be seen from the fig. 6 (b): With the increase of sedimentation value, mid-span stress of beam KL4 was always compressive stress; At the beginning of the experiment, mid-span strain gage of beam KL5 was damaged, and no strain values were measured.

In condition S2, the corresponding relationship curve of settlement of settling column $\mathrm{D}$ and the stress value at both ends of the adjacent beam $\sigma$ was shown in fig. 6 (c). As can be seen from the fig. 6 (c): In the experimental process, stress of beam KL4 on the top of the end closing settling column and at the bottom of the end away from settling column was always compressive stress; With the increase of sedimentation value, stress of beam KL4 on the top of the end away from settling column converted to compressive stress from tension stress; The strain gauge of beam KL 4 at the bottom of end closing settling column wasn't attached to the part which need to be tested.

\section{Conclusion}

In the experimental process, when the differential settlement was 0.004L ( $\mathrm{L}$ is adjacent intercolumnation), frame beams appeared the micro-cracks. The experiment verified code for design of building foundation(GB50007-2011). The allowable subsoil deformation in lower or medium 
compressible soil is $0.002 \mathrm{~L}$ and in high-compressible-foundation-soil is $0.003 \mathrm{~L}$, that regulations has great security.

As to side column settlement,cracks first appeared on the top surface of side beams away from the end of settling column; The main cracks appeared at the underarm parts of beam-column joints, the mid-span top of middle beams, the end away from settling column of beams next to settling column and so on; The RC members were broken for concrete spalling of side beam at bottom away from the end of settling column. As to middle column settlement, cracks first appeared on the top surface of middle beam away from the end of settling column; The main cracks appeared at the top of the end away from settling column of side beams, the mid-span bottom of middle beams, the bottom away from the end of settling column of middle beams. The RC members were broken for concrete spalling of middle beam at bottom away from the end of settling column.

In the experimental process, under the condition of the same settlement, differential settlement had the greatest influence on the adjacent beams and columns; Column next to settling column sustain tension stress on the side away from the settling column where cracks first appeared; Column next to settling column bear compressive stress on the side which near the settling column; It can reveal the place and part of weakness of structure to make for the optimization design of structure, such as the top of the end away from settling column, the bottom of the end closing settling column, and mid-span of beams next to settling column.

\section{References}

[1] Dachuan CHEN, Rongwei CAO and so on. Reason and treatment of an uneven foundation settlement accident of a bottom frame structure house [J]. Building Structure, 2015, 45(9): 43-45.

[2] Jianbo XU. Research on Non-uniformity Settlement of Foundation and Proposing Effective Preventing Countermeasures [D].wuhan: Hunan University, 2006.

[3] Jie MA. Space Work FEM Analysis of Frame Structure of Unequal Settlement [D]. Wuhan: Wuhan University, 2005.

[4] Qiang JIA, Xin ZHANG. Finite element analysis on non-uniform settlement of foundation on RC frame structures [J]. Chinese Journal of Computational Mechanics, 2011, 28(2): 265-269.

[5] O.C. Lee and H.B Harrison, A theoretical study of structure and foundations, J.Struc.Div., Proc. ASCE, 1970, Vol. 96, No.ST2, 177 197.

[6] J.T Christian, Soil structure-interaction tall building, Planning and Design of Tall Buildings, Lehigh U., 1972, Vol. 1a, 967 983.

[7] H.G. Poulos, and E.H Davis, Pile foundation analysis and design, New York: Wiley, 1980.

[8] Yang ZANG. Analysis of effect of the differential settlement on force and deformation of frame structure [D]. Xi'an: Chang'an University, 2010.

[9] Chang LIU and Gang ZHENG. Analysis of the influence of ground unequal settlement on the structure with elastic support model method [J].Journal of Building Structures, 2004, 25(4): 124-128.

[10]Zhenhai GUO and Xiaodong SHI. Reinforced Concrete Theory and Analyse. Beijing: Tsinghua university press, 2011. 